\title{
The theme of violence in nursing theses from the view of technological toolboxes
}

\author{
A temática da violência nas teses de enfermagem na perspectiva das caixas de ferramentas tecnológicas \\ La temática de la violencia en las tesis de enfermería bajo la perspectiva de las cajas de herramientas tecnológicas
}

\section{Emanuella de Castro Marcolino' ORCID: 0000-0002-6135-8853 \\ Renata Clemente dos Santos" ORCID: 0000-0003-2916-6832 \\ Rejane Maria Paiva de Menezes"I' ORCID: 0000-0002-0600-0621 \\ Francisco Arnoldo Nunes de Miranda"'I ORCID: 0000-0002-8648-811X}

'Centro Universitário Unifacisa. Campina Grande, Paraíba, Brazil.

"Universidade Federal da Paraíba. João Pessoa, Paraíba, Brazil. "' Universidade Federal do Rio Grande do Norte. Natal, Rio Grande do Norte, Brazil.

How to cite this article: Marcolino EC, Santos RC, Menezes RMP, Miranda FAN. The theme of violence in nursing theses from the view of technological toolboxes. Rev Bras Enferm. 2020;73(1):e20180018. doi: http://dx.doi.org/10.1590/0034-7167-2018-0018

\section{Corresponding Author:}

Emanuella de Castro Marcolino E-mail:emanuella.de.castro@gmail.com

EDITOR IN CHIEF: Antonio José de Almeida Filho ASSOCIATE EDITOR: Dalvani Marques

Submission: 02-07-2018

Approval: 11-29-2018

\begin{abstract}
Objective: To characterize the data gathering technological tools used in nursing theses on violence from the view of "technological toolboxes". Method: It is a descriptive and documental study, with a qualitative approach, based on Thesis available in the last ten volumes of the Catalogue of Theses and Dissertations of the Center of Nursing Studies and Research (CEPEn). Documents presenting technological tools during the data gathering of its studies were selected, and then classified using "technological toolboxes" according to Merhy. Results: 30 theses were selected, data gathering tools were classified in "technological toolboxes" as lightweight, light-hard, and hard technologies, with uniformity in most researches $(23 ; 76.6 \%)$. Conclusion: Given it is a multifaced phenomenon, violence demands a deeper view, using the most diverse tools for its proper understanding and classification.

Descriptors: Violence; Nursing; Research Design; Investigative Techniques; Nursing Research.
\end{abstract}

\section{RESUMO}

Objetivo: Caracterizar os instrumentos tecnológicos de coleta de dados utilizados em teses de enfermagem sobre violência na perspectiva de "caixas de ferramentas tecnológicas". Método: Estudo descritivo, documental, com abordagem quantitativa baseado em Teses disponíveis nos últimos dez volumes do Catálogo de Teses e Dissertações do Centro de Estudos e Pesquisas em Enfermagem (CEPEn). Foram selecionados documentos que apresentaram instrumentos tecnológicos durante a coleta de dados de seus respectivos estudos, estes foram classificados utilizando as "caixas de ferramentas tecnológicas" segundo Merhy. Resultados: Foram selecionadas 30 teses, a classificação dos instrumentos de coleta de dados nas "caixas de ferramentas tecnológicas" em leve, leve-duras e dura havendo uniformidade na maioria das pesquisas $(23 ; 76,6 \%)$. Conclusão: Por tratar-se de um fenômeno multifacetado a violência exige um olhar mais aprofundado, a partir da utilização dos mais diversos instrumentos para sua adequada compreensão e classificação. Descritores: Violência; Enfermagem; Teses; Técnicas de Investigação; Pesquisa em Enfermagem.

\section{RESUMEN}

Objetivo: Caracterizar los instrumentos tecnológicos de recolección de datos utilizados en tesis de enfermería sobre violencia desde la perspectiva de "cajas de herramientas tecnológicas". Método: Estudio descriptivo, documental, con abordaje cuantitativo, a partir de tesis disponibles en los últimos diez volúmenes del Catálogo de Tesis y Disertaciones del Centro de Estudios e Investigaciones en Enfermería (CEPEn). Se seleccionaron documentos que habían presentado instrumentos tecnológicos durante la recolección de datos de sus respectivos estudios, que fueron clasificados utilizando las "cajas de herramientas tecnológicas" según lo plantea Merhy. Resultados: Se seleccionaron 30 tesis, la clasificación de los instrumentos de recolección de datos en las "cajas de herramientas tecnológicas" fueron leve, leve-duras y dura, y hubo uniformidad en la mayoría de las encuestas (23; $76,6 \%)$. Conclusión: Por ser un fenómeno de múltiples facetas, se deberá profundizar en el tema de la violencia desde la utilización de los más diversos instrumentos para su adecuada comprensión y clasificación.

Descriptores: Violencia; Enfermería; Tesis Académicas; Técnicas de Investigación; Investigación en Enfermería. 


\section{INTRODUCTION}

Violence, as an universal, complex, multifaced, and polysemic phenomenon is defined as the intentional use of force or physical power as a threat or real, against another person, group, community, or even oneself, with great potential to result in injuries, death, psychological harm, poor development or privation ${ }^{(1-3)}$.

As an intentional act, violence is inflicted on a group or person by using force or power, different from injuries or harm caused by involuntary actions and incidents, it crosses throughout human history since it beginnings, being expressed in different social, historical, economic, and cultural contexts, and under certain circumstances as naturalized ${ }^{(2,4)}$.

And, through its roots grounded in the social macrostructure, it can take on diverse conjuncture manifestation in the daily lives of interpersonal relationships, being characterized as an essentially social issue ${ }^{(5)}$.

From the point of view of typology, violence is manifested in three dimensions. Self-inflicted violence, which comprises suicide behaviors and self-abuse; interpersonal violence, which is divided into intrafamilial and in community, the first one being understood as the one happening among intimate partners and family members, while the second is defined as the one occurring in a social environment and, usually, among familiar and unknown people. And the collective violence, which can be understood as the violent acts happening in the macrosocial, political, and economic scope, characterizing the domination of groups and States ${ }^{(6)}$.

From the point of view of the nature of violent acts, violence is classified in four expression modalities, which can occur isolated or along with another type. Physical violence involves the use of force to produce violence. The psychological one comprises verbal or gesture aggressions in order to threaten, humiliate, restrict liberty, and isolate. Sexual violence concerns the many sexual acts performed through threats or violence. Neglecting violence, also called care privation, is understood as the lack of care or abandonment of those in need ${ }^{(5-6)}$.

This is a theme permeated by stigmas and prejudice, besides a crescent occurrence that is difficult to control in contemporary societies. About this exponential fact, it is highlighted that, in Brazil, from the 1980s to 2014, it was observed an increase of $592.8 \%$ of homicides by gunfire, that is, the intentional use of guns to produce violence ${ }^{(7)}$, which is one of the biggest indicators of violence growth nowadays.

The access to information and data gathering tools, in the view of violence research, is a challenge to researchers, since the studied theme is dressed in taboo, stigma, and prejudice. In this sense, the methodological search for the exploration of a multifaced and polysemic phenomenon and the relationship between researcher and phenomenon work as an encounter. The researcher lists the tools considered as most adequate for that action, for example, interviews, questionnaire, focus group, free word association test, life history, among others, being possible to define the methodological research tools according to the proposition of "technological toolboxes", proposed by Merhy in order to explore violence.

The conception of "technological toolboxes", those composed by material and immaterial knowledge and outcomes, which make sense in their relations according to the environment they occupy and its intended end in the health area, may be related to propaedeutic methods and procedures (hard technologies), to knowledge (light-hard technologies) and, the third, to the relations between worker-user (lightweight technologies) ${ }^{(8-9)}$. Data gathering tools used in researches can, thus, be characterized according to the proposition described.

Therefore, it is questioned: how are data gathering tools characterized in Nursing theses on the theme of violence in view of the "technological toolboxes"? The intention, thus, is to characterize the technological tools used for gathering.

\section{OBJECTIVE}

To characterize the technological tools for data gathering data gathering used in Nursing theses about violence under the perspective of "technological toolboxes".

\section{METHOD}

\section{Ethical aspects}

Since it is a documental research, the development of this study dispensed with the authorization of the research ethics committee, therefore, covered by the Resolution no. 510 of the National Health Council from April $1^{\text {st }}, 2016$, which deals with documents and repository of public domain studies ${ }^{(13)}$.

\section{Type of study}

It is a descriptive and documental study with quantitative approach, performed based on studies developed in PhD postgraduate courses in Brazil, presenting the violence phenomenon as the study's object and published in the Catalogue of Theses and Dissertations of the Center of Nursing Studies and Research (CEPEn), of the Brazilian Nursing Association (ABEn). A site that obligatorily registers the abstracts of researches developed in post-graduate nursing programs in Brazil as a specific repository.

The role of encouraging and developing nursing researches played by CEPEn is highlighted, since it is responsible for the national coordination of the National Seminar of Nursing Research (SENPE), for Nursing activities in the National Coordination of Nursing post-graduate courses, with the Coordination for Higher Education Improvement (CAPES), and the Brazilian Society for Science Progress (SBPC), besides the creation and maintenance of the Brazilian Nursing Memory Center, as well As the organ's library ${ }^{(10)}$.

In this study, "technological toolboxes" are seen as each of the tools used in doctorate theses. For data gathering, it was used the catalogues of the last ten chapters and the volumes from no. 24 to 33, referring to 2015 to 2014 of CEPEn/ABEn. The choice for theses was made due to its original character and its relevance for the technological, scientific, social, cultural development and innovation ${ }^{(11)}$.

\section{Population or sample}


In the sample, it was included thesis' abstracts form the last ten chapters indexed in the CEPEn/ABEn database, and the ones that used technological tools for data collection and had violence as their object of study. It was excluded from the sample all dissertations available in the chapters of the CEPEn/ABEn database and documental, bibliographical, reflexive and literature review researches.

\section{Study protocol}

A theses search protocol was designed specifically for this study, with the intention of better guiding the research, and containing the theme, objective, guiding question, search strategy, inclusion and exclusion criteria.

Through peer technique, the data gathering was performed by a pair of post-graduate students, in December 2016 and January 2017. A Microsoft Office Excel ${ }^{\circ}$ spreadsheet was designed and organized into absolute and relative frequencies, represented by charts and figures, containing the following variables: author, Higher Education Institution (HEI), year, place of data gathering, methodological perspective, theoretical-methodological references, and data gathering tool used and classified according to the notion stablished for this study into "technological toolboxes" classified as lightweight, hard, and light-hard.

Hard technologies are characterized by procedures and preparations that allow for the use and handling of materials such as stethoscopes, endoscopes, and others; while lightweight technologies, unlike the previous ones, enable the establishment of relationships and trust bonds between worker-user; and, lastly, light-hard technologies, which are characterized by the intersection of both technologies previously mentioned ${ }^{(8,12)}$.

\section{Statistics and outcome analysis}

Data was analyzed using descriptive statistics on Microsoft Office Excel ${ }^{\circ}$ and presented through absolute and relative frequencies. A chart containing the variables: author, methodological perspective, data gathering tool, and "type of technological toolboxes" applied in the studies was constructed for a better visualization of the theses studied.

\section{RESULTS}

In the ten-year stablished outline (2005 to 2014), it was identified 5,661 abstracts of theses and dissertations; next, using the descriptor "violence" in all ten volumes, a total of 139 theses was obtained, which were then submitted to title reading and, later on, to the reading of their abstracts for selection, according to the study's objective. The final selection covered the stablished inclusion and exclusion criteria, summing up at the end of the search 30 theses distributed per year.

The number of researches on the theme was more expressive in $2005(8 ; 26.7 \%)$, followed by $2010(4 ; 13.3 \%)$ and by 2007, 2009, 2013 , and 2014 , with the same percentage (3; 10\%). This number was reduced in 2006 and 2012 (2;6.7\%), and even lower in 2008 and 2011 (1; 3.3\%); all related to violence in doctorate theses in Brazilian post-graduate nursing programs.

The highest number of publications happened in 2005 (8; $26.66 \%)$. This can be explained by the higher visibility of the analyzed phenomenon in the 2000s. In face of the achieved world population, evinced by the publication of the World Health Report in 2002, which influenced the design and publication of the book Impacto da violência na saúde dos brasileiros (Impacts of violence on the health of Brazilian people) ${ }^{(6)}$.

In a general way, studies on violence published in the CEPEn/ ABEn abstracts in the period of 2005-2014 are presented in Charts 1 and 2 .

Regarding the methodological aspects of the analyzed theses, charts 1 and 2 also portray the description of theoretical-methodological references, data gathering tools used in the studies and their classification according to the concept of toolboxes discussed by Merhy ${ }^{(14)}$.

Chart 1 - Distribution of the qualitative view, theoretical-methodological references, data gathering tool and classification of technological tools from the Merhy view of theses on the Catalogue of Theses and Dissertations of the Brazilian Nursing Association (CEPEn/ABEn) database, from 2005 to 2014

\begin{tabular}{|c|c|c|c|c|c|}
\hline Thesis & Author & $\begin{array}{l}\text { Methodological } \\
\text { perspective }\end{array}$ & Theoretical-methodological references & $\begin{array}{c}\text { Data gathering } \\
\text { tool* }\end{array}$ & $\begin{array}{c}\text { Toolbox according to } \\
\text { Merhy }^{* *}\end{array}$ \\
\hline $\mathrm{T}_{1}$ & Teixeira AVB. & Qualitative & Conservation Model Theory by Myra Levine & I & L/LD/D \\
\hline $\mathrm{T}_{2}$ & Lettiere A. & Qualitative & Complex Thinking Theory by Edgar Morin & I & $\mathrm{L} / \mathrm{LD} / \mathrm{D}$ \\
\hline $\mathrm{T}_{3}$ & Carlos DM. & Qualitative & Complex Thinking Theory by Edgar Morin & I; FG; Op & $\mathrm{L} / \mathrm{LD} / \mathrm{D} ; \mathrm{L} / \mathrm{LD} ; \mathrm{L} / \mathrm{LD}$ \\
\hline $\mathrm{T}_{4}$ & Barreto ACM. & Qualitative & $* * *$ & 1 & $\mathrm{~L} / \mathrm{LD} / \mathrm{D}$ \\
\hline $\mathrm{T}_{5}$ & Martins CS. & Qualitative & $* * *$ & I; Op; CM & L/LD/D; L/LD; LD/D \\
\hline $\mathrm{T}_{6}$ & Oliveira JC. & Qualitative & Social Theory by Pierre Bourdieu & I & $\mathrm{L} / \mathrm{LD} / \mathrm{D}$ \\
\hline $\mathrm{T}_{7}$ & Souto, CMRM. & Qualitative & Hermeneutic Theory by Hans-Georg Gadamer & AT & L /LD/D \\
\hline $\mathrm{T}_{8}$ & Corrêa SA. & Qualitative & $* * *$ & I; Q; Op & L/LD/D; LD; L/LD \\
\hline $\mathrm{T}_{9}$ & Silva LMP. & Qualitative & $* * *$ & I; FG;Op & L /LD/D; L/LD; L/LD \\
\hline $\mathrm{T}_{10}$ & Santinon EP. & Qualitative & Social Theory by Pierre Bourdieu & l; Op & $\mathrm{L} / \mathrm{LH} / \mathrm{H} ; \mathrm{L} / \mathrm{LH} / \mathrm{H}$ \\
\hline $\mathrm{T}_{11}$ & Okabe I. & Qualitative & Social Theory by Pierre Bourdieu & $\mathrm{LH}$ & $\mathrm{L} / \mathrm{H}$ \\
\hline$T_{12}$ & Pereira IV. & Qualitative & $* * *$ & $\mathrm{I} ; \mathrm{Q}$ & $\mathrm{L} / \mathrm{LH} / \mathrm{H} ; \mathrm{LH}$ \\
\hline $\mathrm{T}_{13}$ & Fernandes SLSA. & Qualitative & Imaginary Theory by Michel Maffesoli & I;Op;W & $\mathrm{L} / \mathrm{LH} / \mathrm{H} ; \mathrm{L} / \mathrm{LH} ; \mathrm{L} / \mathrm{LH}$ \\
\hline
\end{tabular}


Chart 1 (concluded)

\begin{tabular}{|c|c|c|c|c|c|}
\hline Thesis & Author & $\begin{array}{c}\text { Methodological } \\
\text { perspective }\end{array}$ & Theoretical-methodological references & $\begin{array}{c}\text { Data gathering } \\
\text { tool* }\end{array}$ & $\begin{array}{c}\text { Toolbox according to } \\
\text { Merhy** }\end{array}$ \\
\hline $\mathrm{T}_{14}$ & Araruna RC. & Qualitative & Imaginary Theory by Michel Maffesoli & $\mathrm{W}$ & $\mathrm{L} / \mathrm{LH}$ \\
\hline $\mathrm{T}_{15}$ & Vendruscolo TS. & Qualitative & Cultural Hegemony Theory by Antonio Gramsci & l; Op; FJ & $\mathrm{L} / \mathrm{LH} / \mathrm{H} ; \mathrm{L} / \mathrm{LH} ; \mathrm{L} / \mathrm{LH}$ \\
\hline $\mathrm{T}_{16}$ & lossi MA. & Qualitative & ${ }^{* * *}$ & $\mathrm{l} ; \mathrm{CNR}$ & $\mathrm{L} / \mathrm{LH} / \mathrm{H} ; \mathrm{LH}$ \\
\hline $\mathrm{T}_{17}$ & Oliveira CC. & Qualitative & Social Theory by Pierre Bourdieu & $\mathrm{W}$ & $\mathrm{L} / \mathrm{LH}$ \\
\hline $\mathrm{T}_{18}$ & Monteiro CFS. & Qualitative & Existentialist Theory by Martin Heidegger & $\mathrm{FG}$ & $\mathrm{L} / \mathrm{LH}$ \\
\hline $\mathrm{T}_{19}$ & Grüdtner DI. & Qualitative & Social Theory by Pierre Bourdieu & $\mathrm{I}$ & $\mathrm{L} / \mathrm{LH} / \mathrm{H}$ \\
\hline $\mathrm{T}_{20}$ & Freitas CASL. & Qualitative & Hermeneutic Theory by Hans-Georg Gadamer & $\mathrm{HDC}$ & $\mathrm{L} / \mathrm{LH}$ \\
\hline
\end{tabular}

Note: ${ }^{I}$ = interview; $Q=$ questionnaire; $F G=$ focus group; $O p=$ participative observation; $W=$ workshops; $C M=$ census map; $A T=$ art-therapy; $L H=l i f e$ history; $F J=$ field journal; $C N R=$ compulsory notification report; $H D C=$ hermeneutic-dialectic circle; ${ }^{* *} \mathrm{~L}=$ lightweight technology; $\mathrm{LH}=$ light-hard technology; $H=$ hard technology; ${ }^{* * *}$ Non-specific thesis.

Chart 2 - Distribution of the quantitative/mixed perspective, methodological-theoretical references, data gathering tool and classification of technological tools from the Merhy view of thesis in the Catalogue of Theses and Dissertations of the Brazilian Nursing Association (CEPEn/ABEn) database, from 2005 to 2014

\begin{tabular}{|c|c|c|c|c|c|}
\hline Thesis & Author & $\begin{array}{l}\text { Methodological } \\
\text { perspective }\end{array}$ & Theoretical-methodological references & $\begin{array}{l}\text { Data gathering } \\
\text { tool* }\end{array}$ & $\begin{array}{c}\text { Toolbox according to } \\
\text { Merhy }\end{array}$ \\
\hline $\mathrm{T}_{21}$ & Priotto EMTP & Quantitative & $* * *$ & Q & LH \\
\hline $\mathrm{T}_{22}$ & Fonseca-Machado MO & Quantitative & $* * *$ & $\mathrm{~S}$ & $\mathrm{LH}$ \\
\hline$T_{23}$ & Andrade, CJM. & Mixed & Social Theory by Pierre Bourdieu & I; Q; Op; W & $\mathrm{L} / \mathrm{LH} / \mathrm{H} ; \mathrm{LH} ; \mathrm{L} / \mathrm{LH} ; \mathrm{L} / \mathrm{LH}$ \\
\hline$T_{24}$ & Teixeira EMS. & Mixed & Bioecological Theory by Urie Bronfenbrenner & I; Q; Op; PR & $\mathrm{L} / \mathrm{LH} / \mathrm{H} ; \mathrm{LH} ; \mathrm{L} / \mathrm{LH} ; \mathrm{H}$ \\
\hline $\mathrm{T}_{25}$ & Gomes NP. & Mixed & Social Representations Theory by Serge Moscovici & I; FWAT & $\mathrm{L} / \mathrm{LH} / \mathrm{H} ; \mathrm{L}$ \\
\hline $\mathrm{T}_{26}$ & Puccia MIR. & Quantitative & $* * *$ & 1 & $\mathrm{~L} / \mathrm{LH} / \mathrm{H}$ \\
\hline $\mathrm{T}_{27}$ & Santi LN. & Mixed & $* * *$ & I; Q; DCR & $\mathrm{L} / \mathrm{LH} / \mathrm{H} ; \mathrm{LH} ; \mathrm{LH}$ \\
\hline $\mathrm{T}_{28}$ & Miranda MIF. & Mixed & $* * *$ & $\mathrm{I} ; \mathrm{Q} ; \mathrm{Op}$ & $\mathrm{L} / \mathrm{LH} / \mathrm{H} ; \mathrm{LH} ; \mathrm{L} / \mathrm{LH}$ \\
\hline $\mathrm{T}_{29}$ & Vieira $A A B$. & Mixed & Social Representations Theory by Serge Moscovici & I & $\mathrm{L} / \mathrm{LH} / \mathrm{H}$ \\
\hline$T_{30}$ & Flores Sullca T. & Quantitative & $* * *$ & 1 & $\mathrm{~L} / \mathrm{LH} / \mathrm{H}$ \\
\hline
\end{tabular}

Note: ${ }^{*} I=$ interview; $Q=$ questionnaire $S=$ scale; $F G=$ focus group; $O p=$ participative observation; $W=$ workshops; $C M=$ census map; $A T=$ art-therapy; $P R=$ photographic record; $F W A T=$ free word association test; $L H=$ life history; $D C R=$ dental clinical record; $F J=$ field journal; $C N R=$ compulsory notification report; $H D C=$ hermeneutic-dialectic circle; ${ }^{* *} L=$ lightweight technology; $L H=$ lighthard technology; $\mathrm{H}=$ hard technology; ${ }^{* * *}$ Thesis did not specify.

Qualitative researches were the most chosen approach (20 theses) in comparison to quantitative ones (10 theses), and they aimed to understand the violence phenomenon in light of theories of psychosociology, phenomenology, communication sociology, anthropology, among others, as a way of widening the discussion and theoreticalmethodological bases, listed in decreasing scale, the social theories proposed by Pierre Bourdieu (6;20\%), Serge Moscovici (2;6.66\%), Michel Mafesolli (2;6.66\%), Edgar Morin (2;6.66\%), Hans-Georg Gadamer (2; $6.66 \%)$, Antonio Gramsci (1;3.33\%), Martin Heidegger (1;3.33\%), Urie Bronfenbrenner (1;3.33\%), and the nursing theory proposed by Myra Levine $(1 ; 3.33 \%)$, in which she proposes the conservation model.

Still regarding the theoretical-methodological bases, it is highlighted that thesis with quantitative approach did not explain this aspect (chart 2), which was present only in qualitative and mixed approaches. Moreover, a significant percentage (12;40\%) of thesis abstracts did not explain the choice for the theoretical references of its object of study.

As data gathering tools to achieve its respective objectives, interviews, participative observation, and the use of questionnaires were the most used ones in the theses. Regarding the classification of these tools based on the toolboxes concept ${ }^{(14)}$, there was a uniformity in theses, given that most studies used for data gathering all three technological perspectives, lightweight, light-hard, and hard ones (23; 76.6\%), according to the proposed references both in qualitative and quantitative/mixed approaches.
The understanding of violence considers the subjectivity of qualitative researches, since it reaches the interpretation of human experiences and the depth in the many faces violence has, just as it highlights the use of theoretical support as the background to guide the way of looking into the studied violence ${ }^{(15)}$.

Most of the analyzed theses explained the use of a theoretical support to base the analysis of violence and to shed light over the explanation of relationships permeating the manifestation of that phenomenon in reality.

The theoretician most mentioned in qualitative and quantitative/mixed theses was Pierre Bourdieu ${ }^{(16)}$. Many authors ${ }^{(17-20)}$ have aimed to explain the diversity of the studied phenomenon by the Bourdieusian perspective ${ }^{(21)}$. The heart of that analysis is based on systemic thinking, in which the social dynamics happen within a field and, on that field, agents, individuals, and groups have specific dispositions, which Bourdieu ${ }^{(16)}$ calls habitus.

The social dynamics on the field is guided by power relations that create individual and group habitus. It is from this socially constructed field that the symbolical power fomenting power relations and violence among individuals operates ${ }^{(22)}$.

Bourdieu ${ }^{(16)}$ emphasizes the symbolic power added to the many forms of violence, highlighting it as invisible, since it is demonstrated by domination forces dressed in beliefs and social roles incorporated in culture. By producing a social consent between dominated and dominant, institutional violence at 
schools are representations of this symbolic power reproduced by the habitus ${ }^{(23)}$.

Another theoretician used by the theses was Edgar Morin, through the Complex Thinking Theory. For Morin ${ }^{(24)}$, phenomena are not simple, being constituted by a tangle of information, which is the greatest challenge for complex thinking, to stablish an articulation between the most diverse research fields and disciplines. When the violence is analyzed, the recursiveness of that phenomenon evinces the complexity involving it, and this complexity is highlighted by Morin ${ }^{(24)}$, demonstrating that there is no way to perceive a cause-effect relation, but a interrelation that is presented by the simultaneity of violence products and producers, which foment it and feed it back ${ }^{(25)}$.

One of the theses has analyzed the violence against pregnant women in light of the conservation theory by Myra Levine, which seed man as a dynamic whole, in constant interaction to the environment. This theoretical nursing model aims to analyze the maintenance and recovery of an individual's physical, mental, social, and spiritual well-being, considering an individual and integral care based on the notion of a holistic and dynamic individual who constantly interacts with the external and internal environment, and who depends on relationships with other people, family, and social environment to keep their health; being that the challenge for the health professional, to reestablish the holism and integrality of a subject who was victim to violence ${ }^{(26)}$.

It is important to highlight the lack of explanations in the theses regarding the use of the theoretical-philosophical-methodological references adopted by the researchers in the construction and base of the study object (12;40\%). Considering that the scientific production of a doctorate research demands the understanding of a phenomenon to be followed by a denser theoretical depth, this fact questions the theses' frailty in this sense, when dealing with violence.

Besides the theoretical-methodological support, data gathering tools represent significant tools to achieve the subjectivities permeating the expression of the many forms of violence. Thus, the choice for data gathering tools represents an important step in the process of research in violence.

To discuss these methodological tools, the concept of "toolboxes" by Merhy is used, in which the author defines technological conceptions of tools for work in health, which can be associated to data gathering tools of researches in violence.

Merhy ${ }^{(14)}$ has listed three types of boxes supporting this work, one related to therapeutic and diagnosing procedures, another one connected to knowledge, and the last one to the relationships between worker-user. It can be said that the first box refers to the concrete technological tools that allow for interventions through equipment, machines and devices, constituting the hard technologies ${ }^{(8)}$.

The second box is constituted by well-defined knowledge which allow for the live work in acts of interaction to the user. In this field, the products of the first toolbox gain meaning as health acts, and the subject handling the technologies cross through the hardness of more structured processes, and the lightweight of more malleable processes. The technologies occurring in this territory are called light-hard ones. The third toolbox is based on subjective relations in the encounter between worker-user, through listening, interest, and the construction of bonds. The technologies involved in the production of this encounter are called lightweight ones ${ }^{(8)}$.

This notion by Merhy ${ }^{(14)}$ can be transposed to the data gathering tools of a scientific research, based on the understanding that gathering tools devices that subside the scientific work and become differentiated scientific technologies. Data gathering tools that are constituted into equipment, electronic devices, and concrete objects recall hard technologies, while the scientific knowledge and the researcher's sharp view refer to light-hard technology, and, lastly, the light interaction between researchers and researched subjects, which the subject leads the data gathering, is lightweight technology.

In this perspective, among the tools that were most mentioned by the theses, interviews were prevalent. It can be considered a widely used research tool, since it is one of the most compete ones in terms of technological classification, and which is framed as lightweight, light-hard, and hard technology. It is lightweight given that its basis is the interrelation between researcher and researched subject, as well as the analysis of figurative elements of that individuals that only arise at the moment of contact, of interaction; it is light-hard since it uses a previously semi-structured script and leads the dialogue according to the researcher's knowledge in the studied area; and, lastly, it uses hard technology when using electronic tools to record interviews ${ }^{(27-28)}$.

Within this context, participative observation, which allows for observing the expression of how actions and acts are manifested in reality, is set as a light-hard technology, which is essentially based on the researcher's scientific knowledge and view ${ }^{(29)}$. Other data gathering tools, such as focus groups and workshops, show great technological complexity, embracing more than one technological levels and demanding versatility of the researcher, as well as some specific data gathering tools, as the FWAT (Free Word Association Test), life history, and hermeneutic-dialectic circle, which also demand this labored technological apprehension of the researcher.

\section{Study limitations}

A limitation of this study is the lack of important information in the abstracts available in the catalogue volumes, just as the way of organizing qualitative data. In some little-detailed cases, such frailties are explained by the facts that some theses are not fully available in virtual bases and libraries, which has restricted further deepening on the researches/theses that were objects of the study.

\section{Contributions to the areas of nursing, health or public health}

This study brings impacts to the nursing area, considering it provides the academic community with a array of many tools and methods used for data gathering in researches in nursing, thus granting them a range of possibilities for the development of further studies, as well as the search for innovating in them. Moreover, understanding the theoretical-philosophical references that arise from a study on the phenomenon of violence enables nurses and researches with a clearer, more consistent 
and objective understanding on that, subsiding them for the praxis and to face violence.

Overall, this study unites theoretical figures that fit the meanders of this multifaced phenomenon, the technology levels proposed by Merhy, by confining each of the analyzed data gathering tools to the technological typology. This set of information, insights, and immersions provides support for reflection, discussions or choices in researches in the area of violence, approaching nursing and beyond it, covering the whole great health area.

\section{CONCLUSION}

The results of this study have shown that the qualitative approach was more evident in the theses of the Catalogue of Theses and Dissertations (CEPEn) of the Brazilian Nursing Association (ABEn) for the analysis of the phenomenon of violence and that, among the technological data gathering tools that prevailed, it was highlighted interviews, participative observation, and the use of questionnaires.

Data gathering tools were organized in light of the "technological toolboxes" as lightweight, light-hard, and hard technologies about violence as the object of study. According to this classification, a homogeneity was observed in its distribution as a polysemic and multifaced phenomenon, lacking a deeper look into the theme, thus encouraging and stimulating researchers to use the many technology and innovation tools available.

It is also shown a divergence among theses regarding the existence of the theoretical-methodological references for basing the violence object. This gap may occur due to not using a theoretical/philosophical landmark to base the understanding of the phenomenon or due to the lack of clarity in the explanation during the design of the theses, as well as it demonstrates a superficiality in their theoretical depth.

\section{REFERENCES}

1. Minayo MCS. Violência e saúde. Rio de Janeiro: Editora Fiocruz; 2006.

2. Siqueira VB. Gender based violence: a social phenomenon of interdisciplinary approach. J Nurs UFPE On Line. 2016;10(1):179-84. doi: 10.5205/reuol.8423-73529-1-RV10012016233.

3. World Health Organization (WHO). World report on violence and health [Internet]. Genebra: WHO; 2002 [cited 2017 Nov 16]. Available from: https://www.who.int/violence_injury_prevention/violence/world_report/en/introduction.pdf

4. Guimarães RCS, Soares MCS, Santos RC, Moura JP, Freire TVV, Dias MD. Impacto na autoestima de mulheres em situação de violência doméstica atendidas em Campina Grande, Brasil. Rev Cuid. 2018;9(1):1988-97. doi: 10.15649/cuidarte.v9i1.438

5. Escorsim SM. Violência de gênero e saúde coletiva: um debate necessário. Rev Katál. 2014;17(2):235-41. doi: 10.1590/ S1414-49802014000200009

6. Ministério da Saúde (BR). Impacto da violência na saúde dos brasileiros [Internet]. Brasília: Ministério da Saúde; 2005 [cited 2017 Nov 16]. Available from: http://bvsms.saude.gov.br/bvs/publicacoes/impacto_violencia.pdf

7. Waiselfisz JJ. Mapa da violência: homicídios por armas de fogo, 2016 [Internet]. São Paulo: Flacso Brasil; 2016 [cited 2017 Nov 16]. Available from: http://flacso.org.br/files/2016/08/Mapa2016_armas_web-1.pdf

8. Merhy EE, Feuerwerker LCM. Novo olhar sobre as tecnologias de saúde: uma necessidade contemporânea. In: Mandarino ACS, Gomberg E, organizadores. Leituras de novas tecnologias e saúde. São Cristóvão: Editora UFS; 2009. p. 29-74.

9. Sabino LMM, Brasil DRM, Caetano JA, Santos MCL, Alves MDS. Uso de tecnologia leve-dura nas práticas de enfermagem: análise de conceito. Aquichan. 2016;16(2):230-9. doi: 10.5294/aqui.2016.16.2.10

10. Ministério da Saúde (BR). Resolução n 510. Trata das especificidades éticas das pesquisas nas ciências humanas e sociais [Internet]. Brasília: Ministério da Saúde; 2016 [cited 2019 Apr 30]. Available from: http://conselho.saude.gov.br/resolucoes/2016/reso510.pdf

11. Leite JL, Neto FRGXN, Cunha ICKO. Centro de Estudos e Pesquisa em Enfermagem (CEPEn): uma trajetória de 36 anos. Rev Bras Enferm. 2007;60(6):621-6. doi: 10.1590/S0034-71672007000600002

12. Coordenação de Aperfeiçoamento de Pessoal de Nível Superior (CAPES). Portal de Periódicos da CAPES [Internet]. Brasília: CAPES; 2017 [cited 2017 Jun 20]. Available from: http://www.capes.gov.br/premiocapesdetese?view=default

13. Chagas MS, Abrahão AL. Care production in health team focused on living work: the existence of life on death territory. Interface Comum Saúde Educ. 2017;21(63):857-67. doi: 10.1590/1807-57622016.0262

14. Merhy EE. $O$ ato de cuidar: a alma dos serviços de saúde. In: Ministério da Saúde (BR). Ver-SUS Brasil: cadernos de textos. Brasília: Ministério da Saúde; 2004. p. 108-37.

15. Oliveira RNG, Fonseca RMGS. Violence as a research object and intervention in the health field: an analysis from the production of the Research Group on Gender, Health and Nursing. Rev Esc Enferm USP. 2014;48(2):31-8. doi: 10.1590/S0080-623420140000800006

16. Bourdieu P. A dominação masculina. Rio de Janeiro: Bertrand Brasil; 2005.

17. Andrade CJM. Equipes de saúde da família e a violência doméstica contra a mulher: um olhar de gênero [dissertation]. São Paulo: Universidade de São Paulo; 2009. doi: 10.11606/T.83.2009.tde-22062009-145809

18. Oliveira JEC. Ações das escolas, através de seus gestores, no processo de enfrentamento da violência escolar [dissertation]. Ribeirão Preto: Universidade de São Paulo; 2009. doi: 10.11606/T.22.2009.tde-29102009-141219 
19. Santinon EP. "Você não enxerga nada": a experiência de mulheres vítimas de violência doméstica e a Lei Maria da Penha [dissertation]. São Paulo: Universidade de São Paulo; 2010. doi: 10.11606/T.83.2010.tde-29042010-115325

20. kabe I. Violência contra a mulher: uma proposta de indicadores de gênero na família [dissertation]. São Paulo: Universidade de São Paulo; 2010. doi: 10.11606/T.7.2010.tde-29042010-105520

21. Lima RCP, Campos PHF. Field and group: a conceptual approximation between Pierre Bourdieu and the social representation theory of Moscovici. Educ Pesqui. 2015;41(1):63-77. doi: 10.1590/S1517-97022015011454

22. Assunção MFM. Notas sobre a dominação social em António Gramsci e Pierre Bourdieu. Sociol Rev Fac Letras da Univ Porto [Internet]. 2016 [cited 2017 Nov 10];31:151-71. Available from: https://ler.letras.up.pt/uploads/ficheiros/14280.pdf

23. Fagundes GA. Algumas reflexões em torno dos conceitos de habitus, campo e capital cultural. Rev Café Sociol [Internet]. 2017 [cited 2018 Jan 5];6(2):103-23. Available from: https://revistacafecomsociologia.com/revista/index.php/revista/article/view/724/pdf

24. Morin E. Introdução ao pensamento complexo. 3a ed. Porto Alegre: Sulina; 2007.

25. Cruz RAO, Araujo ELM, Nascimento NM, Lima RJ, França JRFS, Oliveira JS. Reflections in the light of the Complexity Theory and Nursing Education. Rev Bras Enferm [Internet]. 2017;70(1):236-9. doi: 10.1590/0034-7167-2016-0239

26. Piccoli $M$, Galvão CM. Visita pré-operatória de enfermagem: proposta metodológica fundamentada no modelo conceitual de Levine. Rev Elet Enf. 2005;7(3):366-72. doi: 10.5216/ree.v7i3.897

27. Muylaert CJ, Sarubbi Jr V, Gallo PR, Rolim Neto ML, Reis AOA. Narrative interviews: an important resource in qualitative research. Rev EsC Enferm USP. 2014;48(2):193-9. doi: 10.1590/S0080-623420140000800027

28. D'Espíndula TS, França BHS. Ethical and bioethical aspects in the research interview: the impact on subjectivity. Rev Bioét. 2016;24(3):495502. doi: 10.1590/1983-80422016243149

29. Zamberlan C, Calvetti A, Figueiredo TR, Dei Svaldi J, Siqueira HCH. Técnicas observacionais e a temática qualidade de vida: uma revisão integrativa. Enferm Glob [Internet]. 2011 [cited 2017 Oct 15];10(24):263-71. Available from: www.scielo.isciii.es/pdf/eg/v10n24/pt_revision3.pdf 